\section{Obesidade Mórbida e Intubação Traqueal}

Prezado Editor,

Baseado em publicações de autores que propõem a colocação de travesseiros sob os ombros e a cabeça de pacientes obesos, para facilitar a intubação traqueal, o Dr. Ricardo Francisco Simoni desenvolveu um dispositivo muito útil. Trata-se de um dispositivo na forma trapezoidal, fruto da observação da postura obtida com a colocação dos travesseiros. Incentivei o Dr. Ricardo a enviar uma Carta ao Editor com o propósito de divulgar o invento.

No nosso serviço utilizamos rotineiramente o dispositivo para a intubação traqueal em obesos e demos o nome de "Trapézio de Simoni" em analogia com a "Cunha de Crawford".

Acho que o invento merece ser divulgado.

Sendo o que se apresenta para o momento, reformulo o meu apreço.

Luiz M. Cangiani, TSA

Membro do Conselho Editorial da RBA

Chefe do Dept $^{\circ}$ de Anestesiologia

e Terapia da Dor do Centro Médico de Campinas

Av. Andrade Neves 611

13013-161 Campinas, SP

\section{Morbidly Obese Patients and Tracheal Intubation}

\section{Dear Mrs. Editor}

Based on publications in which some authors propose the placement of pillows under the shoulders and head of obese patients to help tracheal intubation, Dr. Ricardo Francisco Simoni has developed a very useful device. It is a trapezoidal device, fruit of observation of the position obtained with pillows.

I have encouraged Dr. Ricardo to send a Letter to the Editor aiming at spreading his invention. This device is routinely used in our service for tracheal intubation of obese patients and we have called it "Simoni's Trapeze" in analogy with "Crawford's Wedge".

I believe that the invention is worth being divulgated.

Yours truly.

Luiz M. Cangiani, TSA, M.D.

Member of BJA Editorial Board

Chef of Anesthesiology and Pain Treatment

Department, Medical Center of Campinas

Av. Andrade Neves 611

13013-161 Campinas, SP
Dispositivo Útil para Intubação Traqueal no Paciente Obeso Mórbido

A população obesa tem aumentado consideravelmente em quase todo mundo. No Brasil a taxa de prevalência na população feminina é de $13,3 \%$ e na masculina de $7 \%$. Na Europa e nos EUAas taxas de prevalências são de $20 \%$ e $22,5 \%$, respectivamente. A taxa de ascensão varia de $0,5 \%$ a $1 \%$ ao ano nos países desenvolvidos. Somente Japão e Holanda possuem taxas de ascensão estáveis ${ }^{1}$.

Devido a esses números, é de se esperar que tenhamos cada vez mais cada vez mais pacientes desse tipo em nossa prática clínica, não somente para a realização de gastroplastias e banda gástrica, mas também para outros tipos de procedimentos. São várias as peculiaridades anestésicas que se deve conhecer quando de seu manuseio. Pode-se citar que as alterações cardiovasculares, respiratórias e farmacocinéticas fazem parte da lista das mais importantes. Porém, a intubação traqueal (IOT) e a manutenção das vias aéreas foram alvos de recentes discussões no último encontro da ASA, em outubro de 2004.

Nos obesos, o índice de Mallampati, não seria o fator mais eficaz para previsão de IOT difícil. O teste de maior sucesso para tal avaliação seria a medida da circunferência do pescoço. Assim, pacientes obesos teriam $30 \%$ de probabilidade de IOT difícil quando a circunferência do pescoço ultrapassar $60 \mathrm{~cm}$. Somente nesses casos a intubação traqueal com o paciente acordado a fibroscopia seria recomendada ${ }^{2,3}$.

Ponderou-se também, que a relação obesidade mórbida e IOT difícil está sendo supervalorizada ${ }^{4}$. Dois estudos, um com 764 e outro com 100 obesos mórbidos, não conseguiram demonstrar uma correlação evidente entre índice de massa corpórea (IMC) e IOT difícil ${ }^{5,6}$. Porém, quando esses pacientes obesos apresentavam apnéia obstrutiva do sono, existiu forte correlação com IOT difícil ${ }^{7}$. Nesses pacientes, um estudo mostrou a presença de grande quantidade de tecido conjuntivo frouxo paratraqueal ${ }^{8}$.

Ressaltou-se também nesse mesmo congresso, que na maioria das vezes quando a IOT não era possível com laringoscopia direta, o problema encontrava-se no posicionamento inadequado do paciente ${ }^{3,4}$ (Figura 1).

Na nossa revista (Rev Bras Anestesiol) alguns autores mostraram os cuidados que se deve ter antes de se efetuar a larincoscopia direta. A avaliação criteriosa das vias aéreas, a utilização de coxins sob os ombros, a flexão do dorso da mesa foram demonstradas como manobras eficazes para o correto posicionamento desses pacientes, proporcionando a extensão da coluna torácica e flexão da coluna cervical com o favorecimento da articulação atlanto-occipital ${ }^{9,10}$ (Figura 2). Observando-se as últimas ilustrações publicadas na Rev Bras Anestesiol e no último Refresher Course da ASA 2004, idealizei um coxim único com o formato de trapézio. O dispositivo foi confeccionado com espuma de densidade 33 e envolto em lona lavável, cujas medidas estão apresentadas na figura 5 (Figuras 3, 4 e 5). 


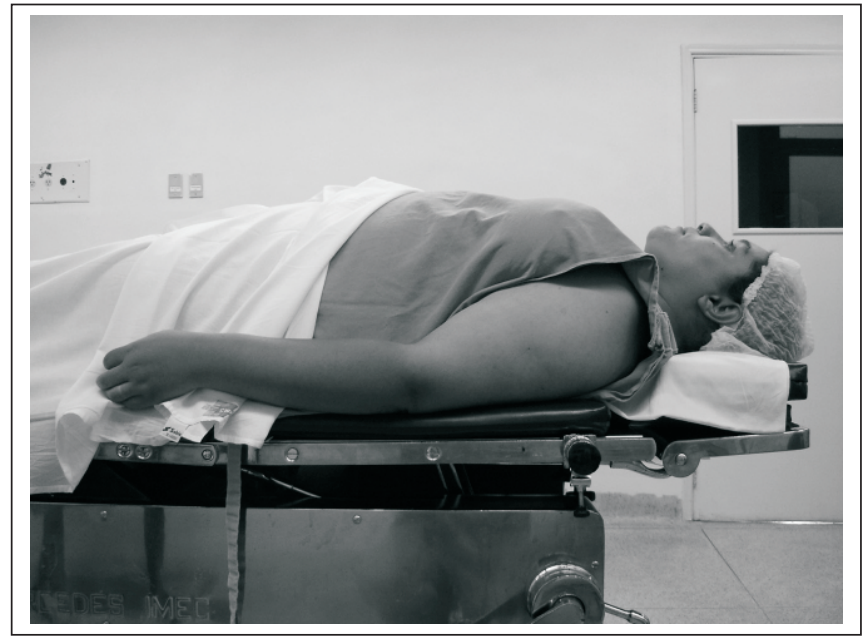

Figura 1 - Posicionamento Habitual

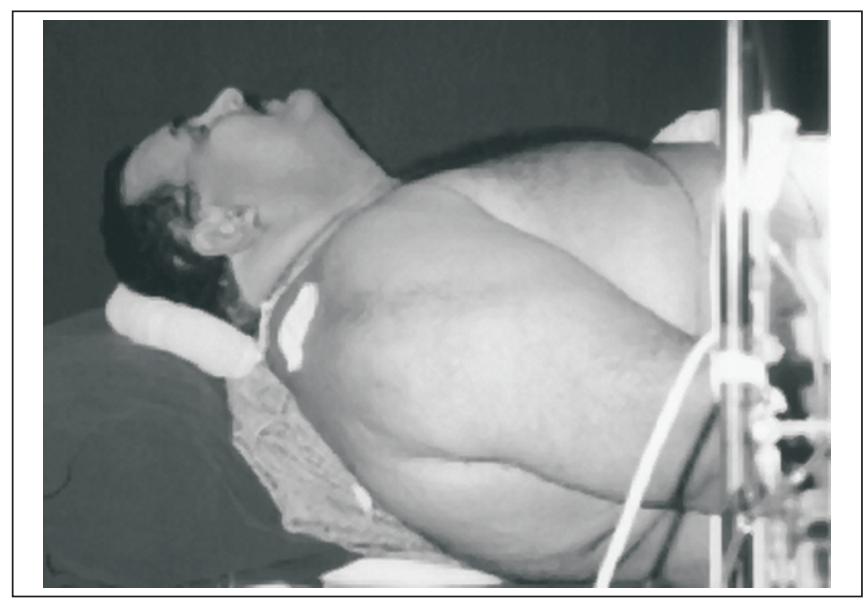

Figura 2 - Método Proposto por Souza e Porsani ${ }^{9}$

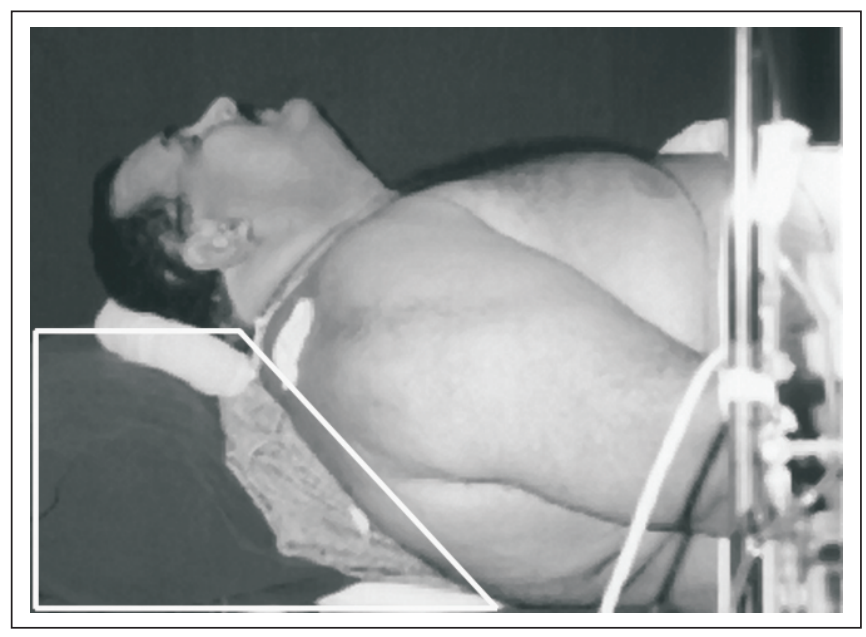

Figura 3 - Mostra que o Conjunto de Travesseiros formam uma Figura Trapezoidal

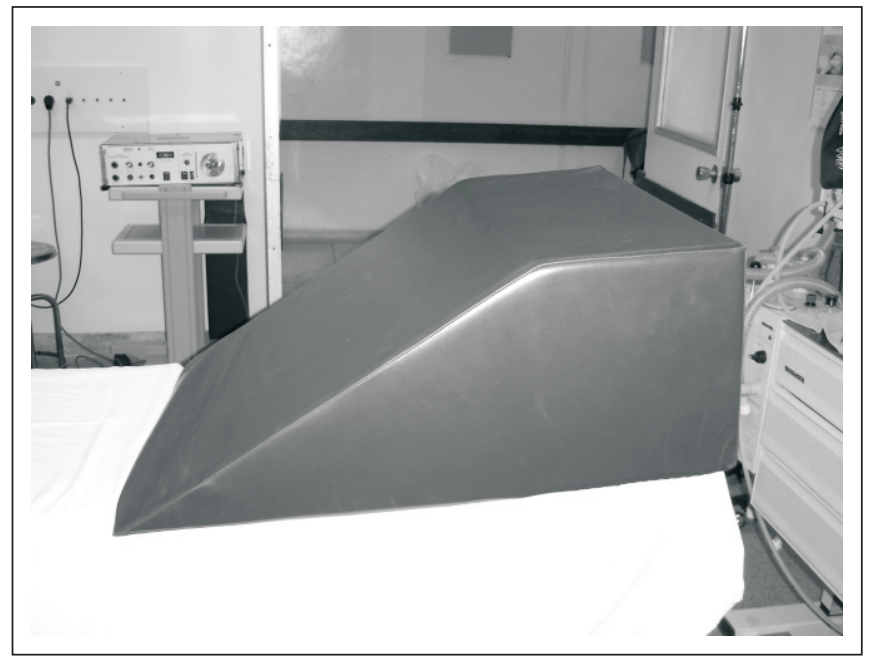

Figura 4 - Dispositivo em Forma Trapezoidal

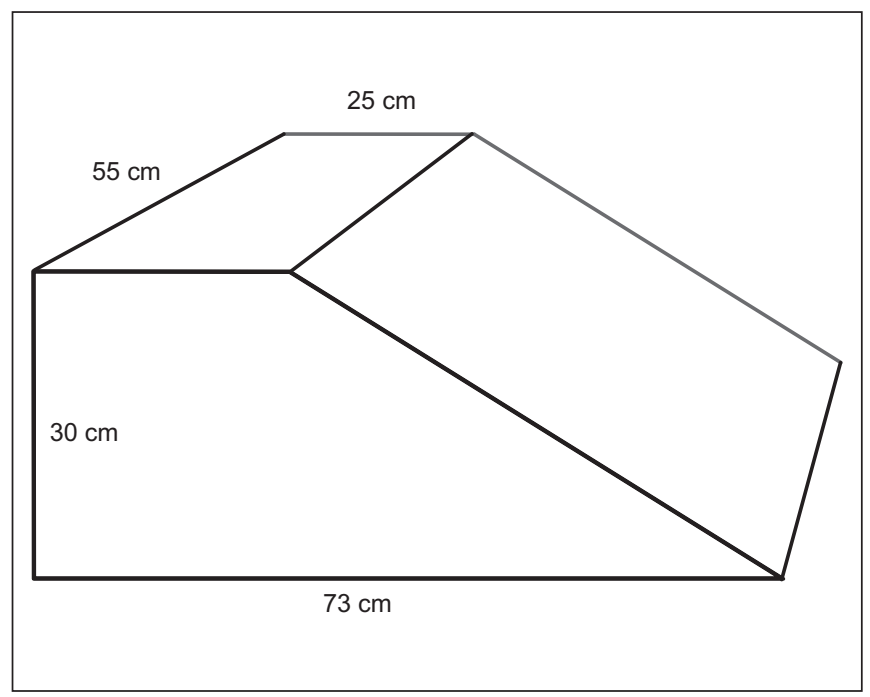

Figura 5 - Medidas do Dispositivo Proposto

Nota-se que para haver posicionamento correto de obesos, deve-se traçar uma linha imaginária entre o meato acústico externo e o esterno do paciente, e que tal linha deve estar paralela ao solo ${ }^{3}$ (Figura 6).

O uso desse dispositivo único em formato de trapézio elimina a utilização de inúmeros lençóis dobrados, cobertores e travesseiros diversos que seriam necessários para se obter tal efeito. Pequenas variações podem ser feitas com pequenos travesseiros colocados sob a cabeça do paciente (Figura 7). Observando-se mais atentamente, essa posição para IOT também pode ser conseguida com flexão do dorso da mesa de operação e com a cabeceira colocada paralela ao solo. Porém, não são todas as mesas que teriam tal recurso e para alguns pacientes grandemente obesos é necessário adaptar-se duas mesas para realização da operação proposta. 


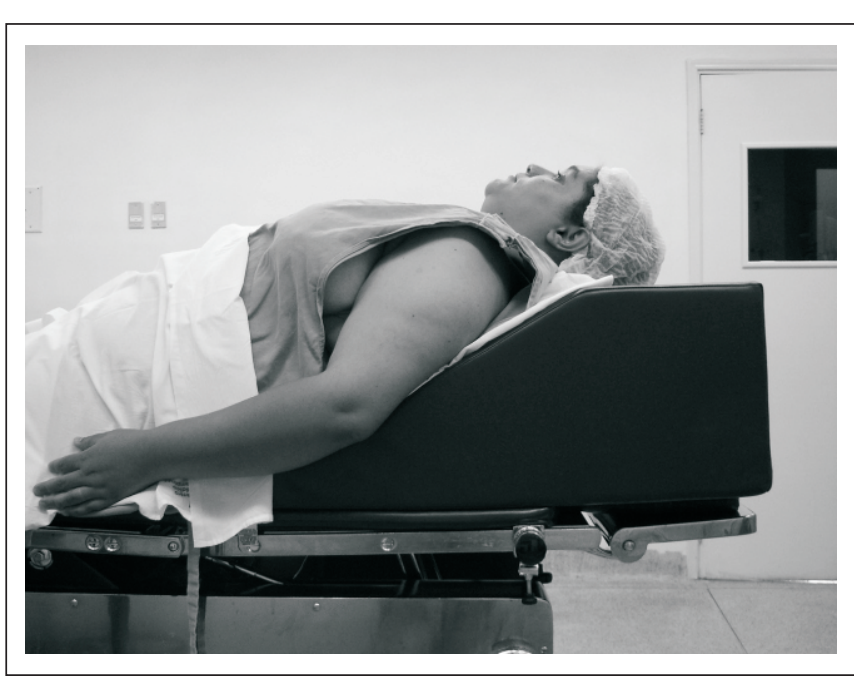

Figura 6 - Utilização do Dispositivo Trapezoidal

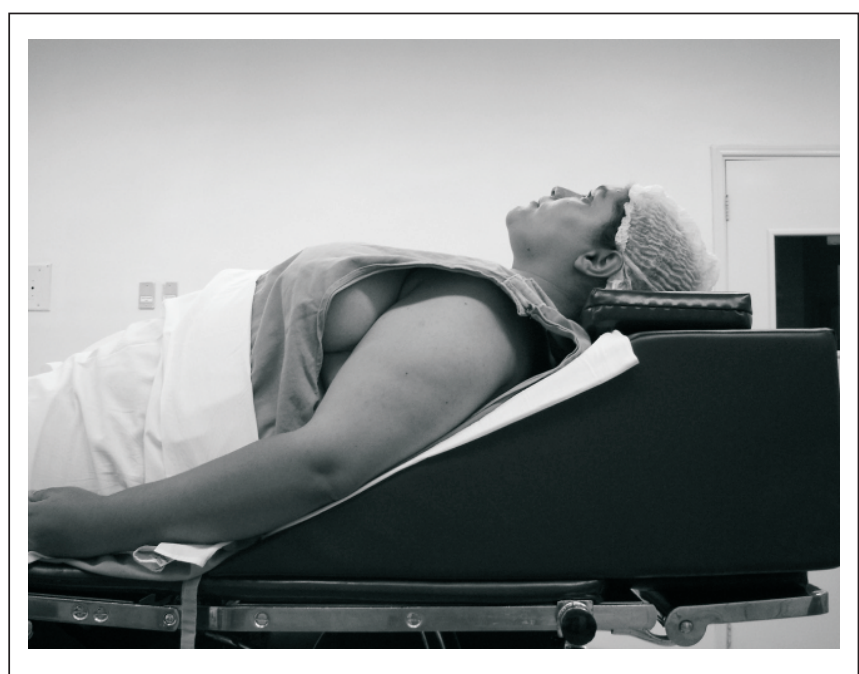

Figura 7 - Colocação de um Travesseiro do mesmo Material para Pequenos Ajustes (se necessário)

Com a utilização do coxim proposto não só a IOT é facilitada, mas também a ventilação dos obesos mórbidos é mais eficaz, resultado do deslocamento distal das mamas e do abdômen. O próprio paciente, quando colocado nessa posição, relata em muitas vezes, maior facilidade nos movimentos ventilatórios.

Atenciosamente.

Ricardo Francisco Simoni, TSA

Membro do CET/SBAdo Instituto Penido Burniere Centro Médico de Campinas.

Rua Cel. Francisco Andrade Coutinho, 222/12

13025-190 Campinas, SP

E-mail: ricaboss@terra.com.br

\section{Tracheal Intubation of Morbidly Obese Patients: A Useful Device}

Obese population has considerably increased almost everywhere. In Brazil, incidence on female population is $13.3 \%$ and on male population is $7 \%$. In Europe and the USA, prevalences are $20 \%$ and $22.5 \%$, respectively. Ascension rate varies from $0.5 \%$ to $1 \%$ a year in developed countries. Only Japan and The Netherlands have stable ascension rates ${ }^{1}$.

Due to these figures, it is to be expected that increasingly more obese patients will be seen in our clinical practice, not only for gastroplasties and gastric bands, but also for different types of procedures. Several anesthetic peculiarities should be understood to manage such patients. It can be said that cardiovascular, respiratory and pharmacokinetic changes are some of the most important. However tracheal intubation (TI) and airway maintenance were the focus of recent discussions during the latest ASA meeting in October 2004.

Mallampati index would not be the most effective factor to predict difficult TI in obese patients. Most successful test for such evaluation would be neck circumference measurement. So, obese patients would have $30 \%$ probability of difficult TI when neck circumference would be above $60 \mathrm{~cm}$. Only for these cases tracheal intubation with awaken patients would be recommended $^{2,3}$.

It has also been discussed that morbid obesity/difficult TI ratio is being overvalued ${ }^{4}$. Two studies, one with 764 and the other with 100 morbidly obese patients, were unable to show evident correlation between body mass index (BMI) and difficult $\mathrm{TI}^{5,6}$. However, when obese patients presented obstructive sleep apnea, there has been strong correlation with difficult $\mathrm{Tl}^{7}$. A study has shown the presence of large amounts of weak paratracheal connective tissue in these patients ${ }^{8}$.

This same meeting has stressed that most times when TI was impossible with direct laryngoscopy, the problem was inadequate patients' position ${ }^{3,4}$ (Figure 1).

Some authors have shown in our journal (Bras J Anesthesiol) cares to be taken before direct laryngoscopy. Thorough airways evaluation, pads under shoulders and table bending were considered effective maneuvers to adequately position these patients, providing thoracic column extension and cervical column flexion favoring atlanto-occipital joint ${ }^{9,10}$ (Figure 2).

Observing recent illustrations published by Bras $\mathrm{J}$ Anesthesiol and after the latest ASA2004 Refresher Course, I have developed a single trapezoidal pad. Device was manufactured with density 33 foam and was wrapped in washable canvas, the measures of which are shown in Figure 5 (Figures 3, 4 and 5).

Note that to correctly position obese patients, an imaginary line should be drawn between external acoustic meatus and sternum, and such line should be parallel to the ground ${ }^{3}$ (Figure 6).

This single trapeze-shaped device eliminates the need for numerous folded sheets, blankets and different pillows which would be needed to obtain such effect. Minor variations could be achieved with small pillows placed under patient's head (Figure 7). 


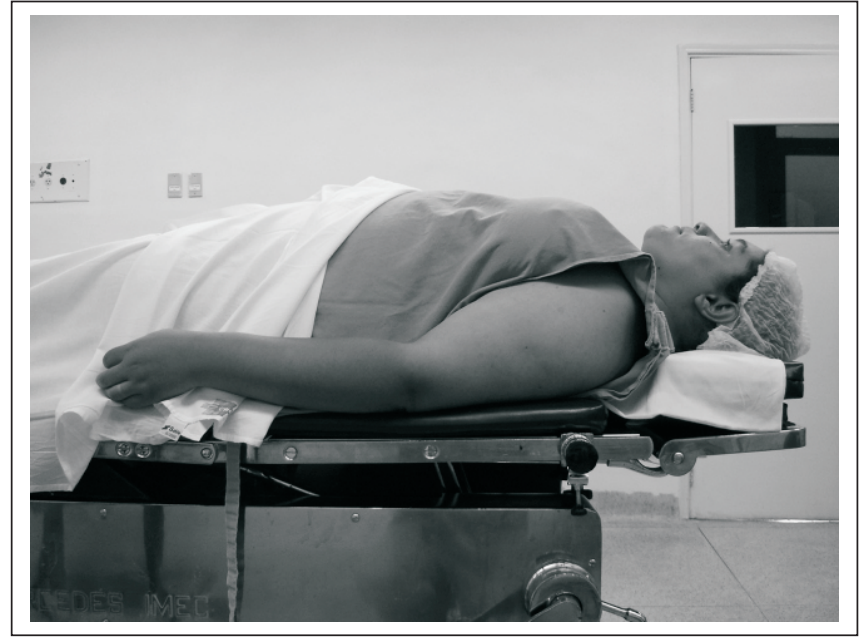

Figure 1 - Normal Position

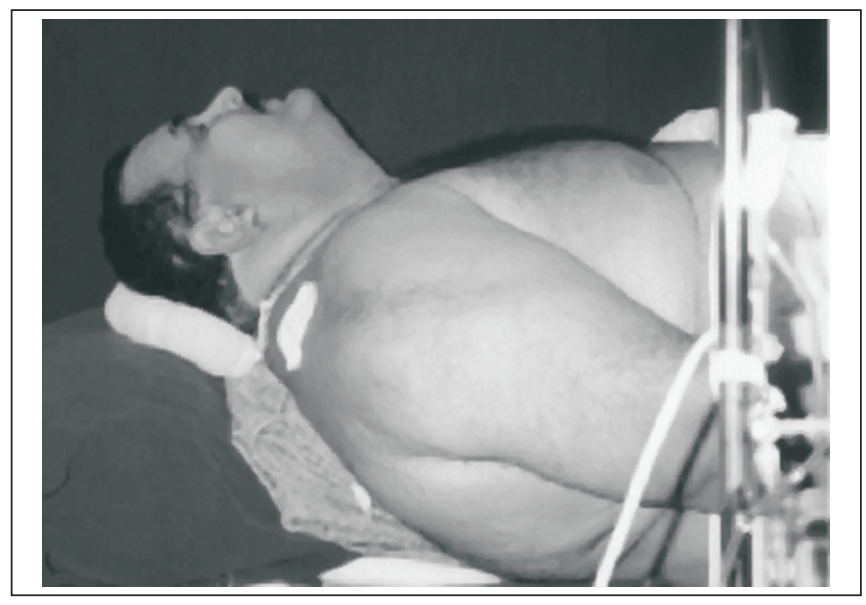

Figure 2 - Method Proposed by Souza \& Porsani ${ }^{9}$

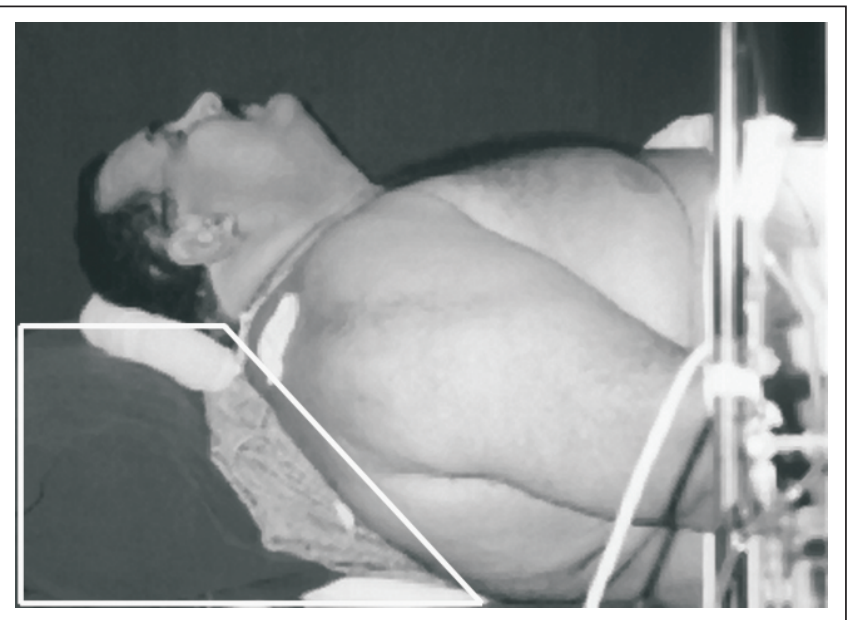

Figure 3 - Shows that the Set of Pillows forms a Trapezoidal Figure

Revista Brasileira de Anestesiologia Vol. 55, № 2, Março - Abril, 2005

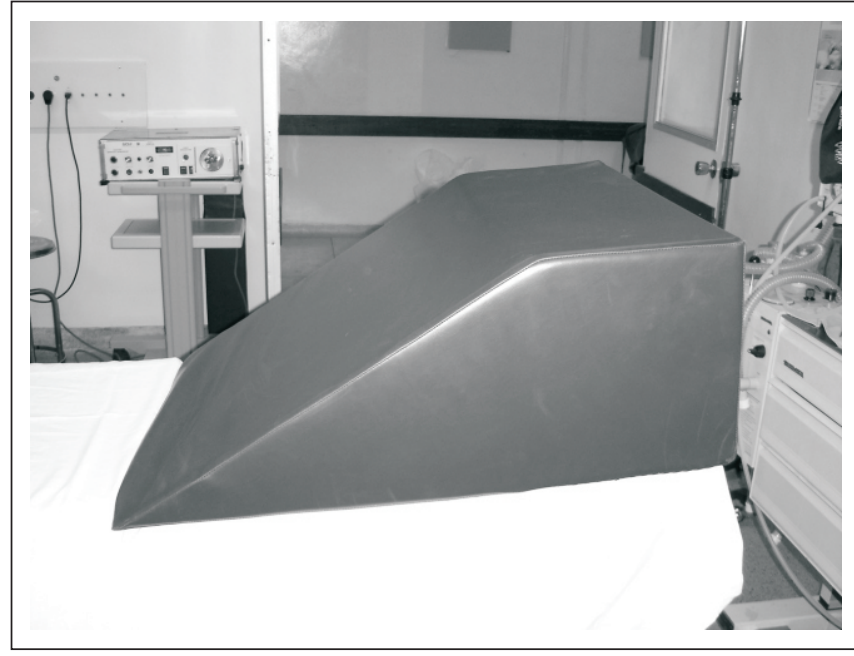

Figure 4 - Trapezoidal Device

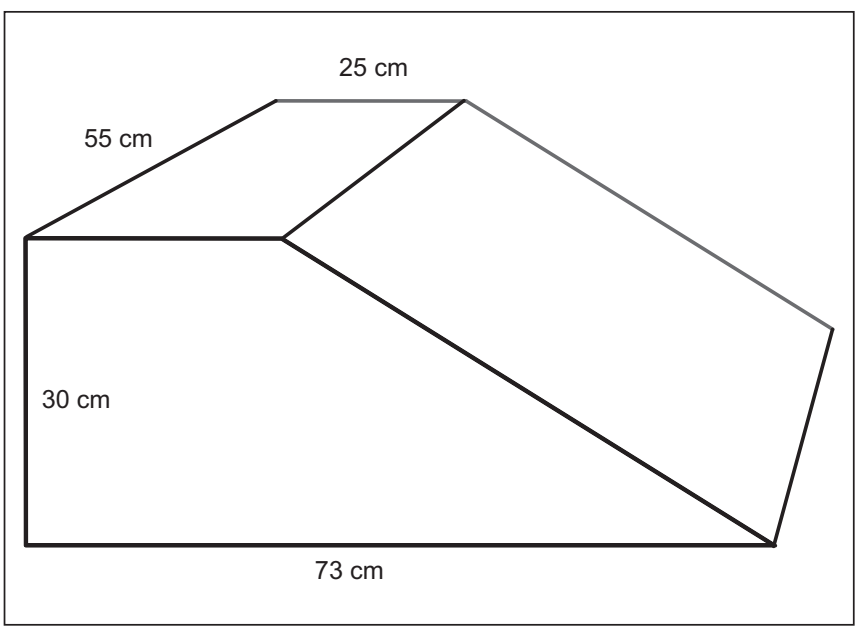

Figure 5 - Measures of Proposed Device

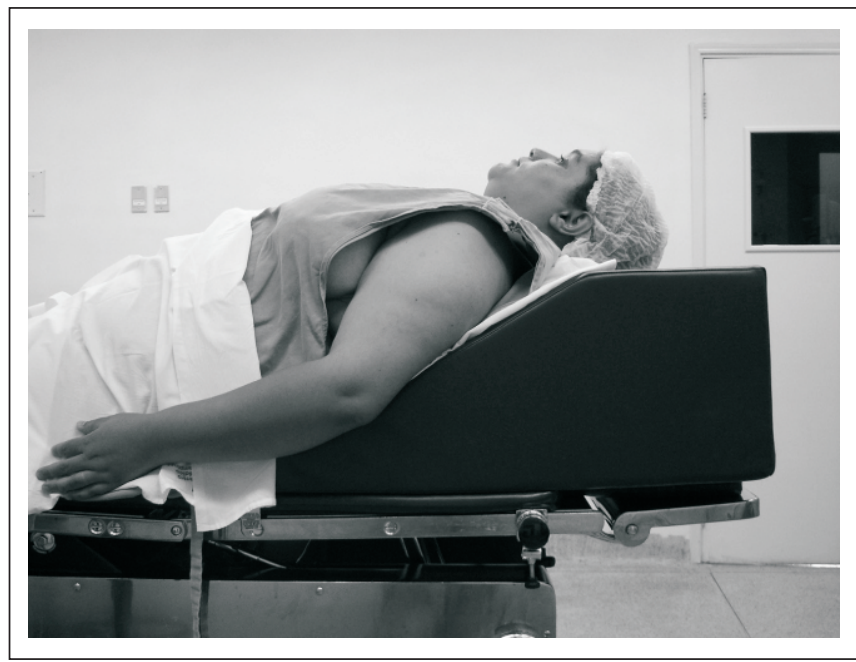

Figure 6 - Trapezoidal Device Use 


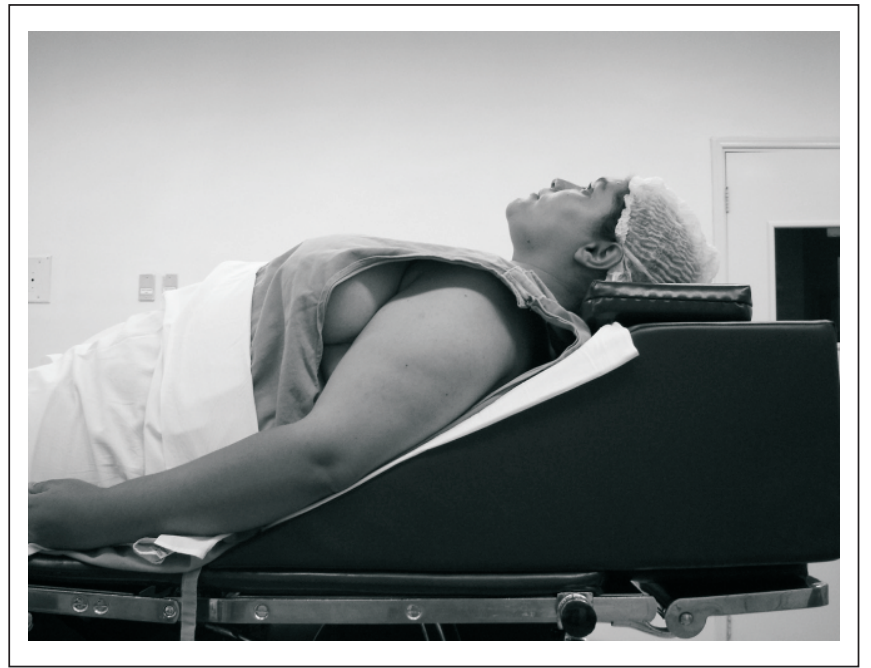

Figure 7 - Placement of a Pillow of the same Material for Minor Adjustments (if needed)

After careful observation, this TI position may be also obtained by bending the operating table with headrest parallel to ground. However not all tables have this facility and for some very obese patients two tables would have to be adapted to perform the proposed operation.

With our pad, not only $\mathrm{TI}$ is made easier, but also morbidly obese patients' ventilation is more effective as result of distal shift of breasts and abdomen. Patients themselves, when placed in this position, very often report easier ventilatory movements.

Yours truly.

Ricardo Francisco Simoni, TSA, M.D.

Member of CET/SBAdo Instituto Penido Burnier and Centro Médico de Campinas.

Rua Cel.Francisco Andrade Coutinho, 222/12

13025-190 Campinas, SP

E-mail: ricaboss@terra.com.br

\section{REFERÊNCIAS - REFERENCES}

01. Mancini MC - Diagnóstico e Classificação da Obesidade, em: Garrido Júnior AB - Cirurgia da Obesidade, São Paulo: Atheneu, 2002;1-7.

02. Ogunnaike BO, Jones SB, Jones DB et al - Anesthetic considerations for bariatric surgery. Anesth Analg, 2002;95:1793-1805.

03. Brodsky JB - Anesthesia for Bariatric Surgery, em: Refresher Course ASA, 2004;506.

04. Neligan PJ - Bariatric Medicine: Clinical Implications of Morbid Obesity, em: Refresher Course ASA, 2004;121.

05. Ezri T, Waters RD, Szmuk P et al - The incidence or class "zero" airway and the impact of Mallampati score, age, sex, and body mass index on prediction of laringoscopy grade. Anesth Analg, 2001;93:1073-1075.

06. Brodsky JB, Lemmens HJ, Brock-Utne JG et al - Morbid obesity and tracheal intubation. Anesth Analg, 2002;94:732-736.

07 . Erzi T, Medalion B, Weisenberg M et al - Increased body mass index per se is not a predictor of difficult laryngoscopy. Can $\mathrm{J}$ Anaesth, 2003;50:179-183.

08. Erzi T, Gewurtz G, Sessler DI et al - Prediction of difficult laryngoscopy in obese patients by ultrasound quantification of anterior neck soft tissue. Anaesthesia, 2003;58:1111-1114.

09. Souza LR, Porsani DF, Branco A - Posicionamento do paciente com obesidade mórbida para intubação traqueal. Rev Bras Anestesiol, 2000;50:484-485.

10. Braga AFA, Silva ACM, Cremonesi E - Obesidade mórbida: considerações clínicas e anestésicas. Rev Bras Anestesiol, 1999;49:201-212. 